\title{
Impacts of Climate Change (EI Nino, La Nina, and Sea Level) on the Coastal Area of Cilacap Regency
}

\author{
Lilik S. Supriatin* and Martono \\ Centre of Atmospheric Science and Technology (LAPAN) \\ Jl. Dr. Djundjunan 133 Bandung, West Java \\ *)Corresponding author (e-mail: lilik_lapan@yahoo.com)
}

\begin{abstract}
This research was conducted to determine the impact of El Nino and La Nina on rainfall as well as the impact of El Nino, La Nina, and sea level on coastal flooding in Cilacap Regency. The methods used in this study were statistical analysis and simulation. The results of this study were El Nino caused diminished rainfall in Cilacap regency between 295 to $1665 \mathrm{~mm}$. Meanwhile, La Nina caused surplus rainfall between 189 - $691 \mathrm{~mm} /$ year in compared with annual climatological rainfall. When ENSO phenomenon (El Nino) occurred, it caused sea level anomaly to fall, including in 1994, 1997, and 2002 of $-11.63 \mathrm{~cm},-11.5 \mathrm{~cm}$, and $-4.95 \mathrm{~cm}$, respectively. Meanwhile, in La Nina years in 1999 and 2000, the sea level anomaly enhanced by $2.55 \mathrm{~cm}$ and $5.03 \mathrm{~cm}$, respectively. The result of sea level projection by employing simulation model in this study was compared with the simulation results of the IPCC that obtained a correlation coefficient $r$ of 0.99. Based on the simulation results, the 8 (eight) subdistricts in Cilacap Regency located in the coastal area potentially endure flood due to the impacts of global warming and La Nina with a diverse predicted year of occurrence depending on the altitude of each sub-district.
\end{abstract}

Keywords: Climate change, El Nino, La Nina, sea level, coastal area.

\begin{abstract}
Abstrak. Telah dilakukan penelitian untuk mengetahui dampak dari El Nino dan La Nina pada curah hujan serta dampak dari El Nino, La Nina, dan tinggi muka laut pada penggenangan kawasan pesisir di Kabupaten Cilacap. Metode yang digunakan adalah analisis statistik dan simulasi. Hasil dari penelitian ini adalah El Nino di kabupaten Cilacap mengurangi curah hujan antara 295 sampai 1665 mm daripada curah hujan klimatologis. Sementara La Nina di kabupaten Cilacap menambah air hujan berkisar antara 189 - 691 mm/tahun dibandingkan dengan curah hujan tahunan klimatologis. Ketika fenomena ENSO (El Nino) terjadi maka anomali tinggi muka Laut Selatan Jawa untuk tahun 1994 adalah turun -11,63 cm, tahun 1997 anomali sebesar $-11,5 \mathrm{~cm}$ dan tahun 2002 adalah $-4,95 \mathrm{~cm}$. Sedangkan sewaktu terjadi La Nina, anomali tinggi muka Laut Selatan Jawa untuk tahun 1999 adalah naik 2,55 cm dan tahun 2000 sebesar 5,03 cm sehingga dapat disimpulkan El Nino mengurangi tinggi muka laut dan sebaliknya La nina meningkatkan tinggi muka laut. Hasil simulasi proyeksi tinggi muka laut dari penelitian ini jika dibandingkan dengan simulasi dari IPCC menghasilkan koefisien korelasi $r=0,99$. Berdasarkan penelitian ini juga terdapat 8 kecamatan di wilayah kabupaten Cilacap yang berdasarkan proyeksi kenaikan tinggi muka laut akan tergenang. Waktu tergenangnya tergantung dari letak ketinggian lokasi (kecamatan) dari permukaan laut.
\end{abstract}

Kata kunci: perubahan iklim, El Nino, La nina, tinggi muka laut, pesisir.

\section{Introduction}

Climate change becomes a phenomenon endured by humankind in this era including in Indonesia. In fact, high intensity of rainfall occurred in most of regions in Indonesia in August when it should have been a month of dry season. Moreover, hazards took place in some flood-prone area like Jakarta. Susandi et al. (2008) suggested that climate change has brought in two main effects that occurred in the bottom layer of the atmosphere. They were high rainfall and sea level rise.

Some indicators of climate change were increased incidence of extreme climate (ENSO and La Nina) and the rise in sea level that could lead to tidal flood (flooding due to rising sea levels) (Ashok and Saji, 2007; Ratnaningayu, 2009; Sahu et al., 2010). 
Similarly, Amri and Arifin (2016) asserted that climate change characterized by extreme weather, rise of sea level and temperature, shifting seasons, and high rainfall intensity, has affected the coastal ecosystem and human life. Intergovernmental Panel on Climate Change (IPCC, 2007) explained that the global mean precipitation increased by $2 \%$ in the last decade. Lansigan et al. (2000) also explicated that El Nino Southern oscillation (ENSO) causes late onset and early termination the rainy season.

Indonesia as the largest archipelago country in the world as well as other countries located on the edge of the ocean and coastal zone are highly vulnerable to the impacts of climate change (Joseph, 2010). The impacts of climate change affected the entire production fields that are located on the coastal zone. Moreover, cultivation activities situated on the coastal area are mostly fishery, tidal wetland, and salt marshes.

Constant sea level rise will likely disrupt the physical processes, economic activities, and social system in the coastal areas (Li, et al., 2009). Extreme natural phenomenon, i.e., La Nina, also has an effect on sea level rise that can lead to a rise by $15 \mathrm{~cm}$. However, it was predicted that La Nina phenomenon would be lengthened with intensified frequency in the future. In addition to sea level rise and high intensity of rainfall, La Nina also increases the wave height. The higher intensity of rainfall and sea level, the higher the potential of flood and the loss of agricultural land in the coastal area. Contradictory, El Nino is a phenomenon that causes diminished rainfall and declined sea level in Indonesia.

Cilacap Regency is one of regencies in Central Java Province which borders the sea (the Indian Ocean). Eight sub-districts in Cilacap Regency covering Kampung Laut, South Cilacap, Central Cilacap, South Cilacap, Adipala, Binangun, Nusawungu, and Kesugihan are located in and directly adjacent to the Indian Ocean (coastal areas). The topography of sub-districts in Cilacap Regency was used as the background to determine the study site. This study aimed to determine the increase and decrease of rainfall during $\mathrm{La}$ Nina and El Nino, to determine the sea level during El Nino and La Nina and the projected sea level for the next few years in the coast of Cilacap, to investigate the potential of flood in the coastal area (sub-districts) as the impact of sea level rise.
Several studies had been conducted to partially assess the effect of ENSO on rainfall, but this study incorporated the impacts of climate change (El Nino and La Nina) on rainfall and sea levels, as well as the impacts of sea level rise on coastal area. In addition, this research was initial research that employed simulation method for the projection by using Powersim Constructor 2.5 software.

\section{Research Methods}

This study analyzed the monthly rainfall data of Cilacap Regency from 1984 to 2013), which was obtained from BMKG Cilacap. In addition, monthly sea level data from 1993 to 2014 derived from NOAA Oceanwatch (http:/ / pifsc-oceanwatch.irc.noaa.gov/las/ servlets/dataset) was also examined. It was supported by topographic data of altitude in the 8 (eight) sub-districts. The methods were statistical analysis) and simulation method for projection by using Powersim Constructor 2.5 software.

\section{Results and Discussions}

Figure 1 illustrates the annual climatological rainfall from 1984 to 2013 (30 years) of Cilacap Regency. Based on Figure 1, the annual mean rainfall could be determined, which was $2678 \mathrm{~mm}$.

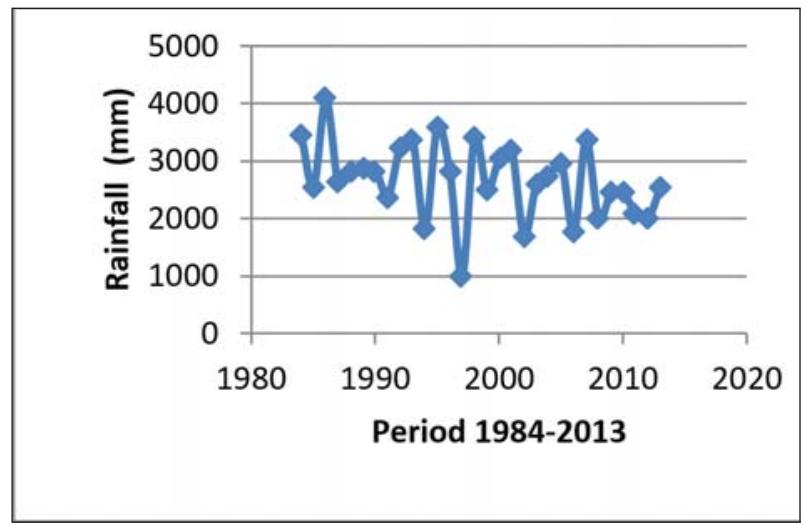

Figure 1. Annual rainfall in 1984-2013 in Cilacap Regency.

This study compared the annual mean rainfall and the annual climatological rainfall when El Nino and La Nina occurred. It found out the rainfall during El Nino years was lower while it was higher in La Nina years. Nevertheless, not all the annual rainfall of those years was higher than the annual 
climatological rainfall. It was recorded that in 1984 - 2013, there were four time occurrences of El Nino (1991, 1994, 1997, and 2002) and four time occurrences of La Nina $(1989,1999,2000$, and 2007). Figure 2 presents the annual rainfall as El Nino and La Nina occurred.

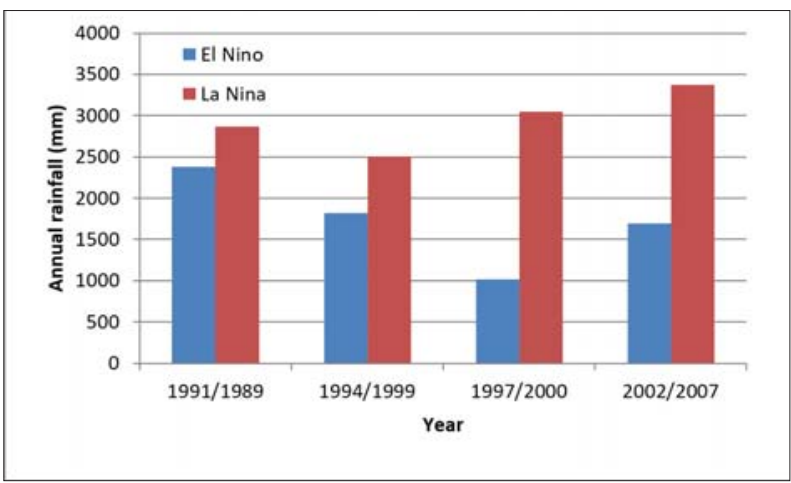

Figure 2. Annual rainfall in the years of El Nino and La Nina phenomenon.

Based on Figure 2, it can be seen that when El Nino occurred, annual rainfall was less than the year of La Nina's occurrence. Furthermore, the comparison between annual rainfall in El Nino years and annual climatological rainfall in Cilacap Regency showed the first was higher with difference between 295 to $1665 \mathrm{~mm}$. The results of this study was similar to Estiningtyas et al. (2007) which demonstrated during El Nino phenomenon, annual rainfall of Cilacap Regency was diminished approximately 923 $\mathrm{mm}$. When El Nino took place in 1997 and 2002, annual rainfall was diminished every month, whereas in 1991 and 1994, annual rainfall was decreased merely in the dry months (from May to September).

Subsequently, in the years when La Nina occurred, there was surplus rainfall ranging between 189 to $691 \mathrm{~mm} /$ year in compared with annual climatological rainfall. The results confirmed the findings of Subagyono and Surmaini (2007) that concluded surplus rainfall during La Nina of approximately $40 \mathrm{~mm} /$ month or $480 \mathrm{~mm}$ /year, which was in the range of the finding of this study.

Figure 3 presents the monthly mean sea level of South Java Sea in the observation period of 1993-2014. Cilacap is situated in and directly adjacent to the South Java Sea. Based on Figure 3, then the annual mean sea level of the South Java Sea was approximately $56 \mathrm{~cm}$. To determine the influence of ENSO on the South Java Sea, evaluation on those averages was carried out. Figure 4 presents the sea level anomaly of South Java Sea in compared with the annual mean sea level.

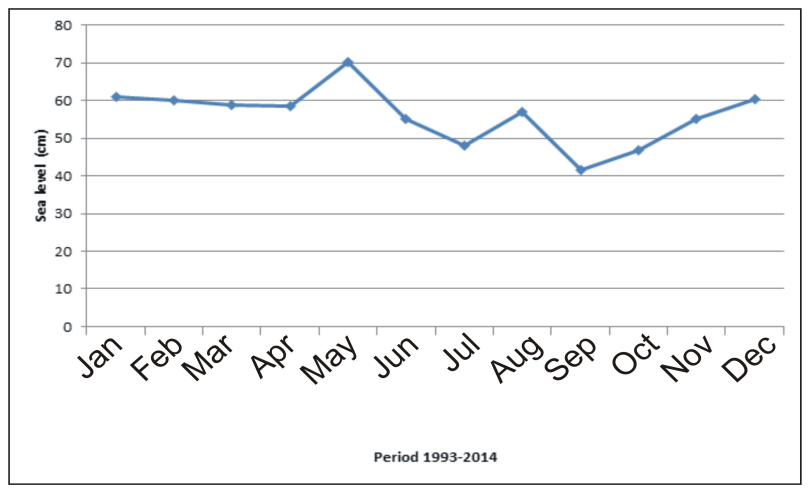

Figure 3. Monthly mean sea level of Java South Sea.

Figure 4 demonstrates when the ENSO phenomenon (El Nino) occurred, sea level anomaly in 1994, 1997, and 2002 were, -11.63 $\mathrm{cm},-11.5 \mathrm{~cm}$, and $-4.95 \mathrm{~cm}$, respectively. Meanwhile, during La Nina, sea level anomaly in 1999 and 2000 were $+2.55 \mathrm{~cm}$ and $+5.03 \mathrm{~cm}$, respectively. So it can be concluded when El Nino occurred, the sea level anomaly of South Java Sea was less than the annual mean sea level. It was contrast with La Nina that caused upwelling. It was caused by the weather during El Nino, warm water that should be in the region of Indonesia moves to the East, thereby it reduces the volume of the ocean and sea level, whereas in La Nina, warm water would move into the territorial water of Indonesia thereby increasing the volume of ocean and sea level.

The finding confirmed the study carried out by Sofian et al. (2007) that suggested the sea level rise during La Nina was caused by strong trade winds in the Pacific Ocean move the mass of water vapor (warm water) from the East Pacific (the coasts of Peru) to the territorial water of Indonesia, including the South Sea Java.

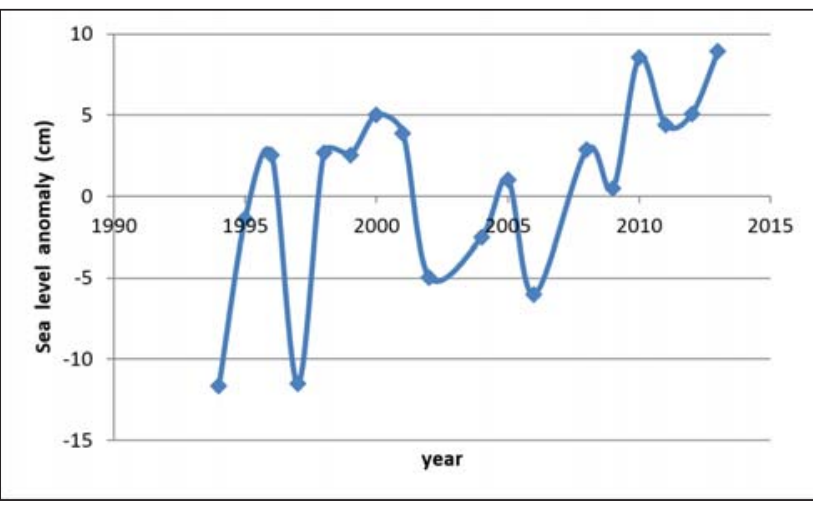

Figure 4. Sea level anomaly of South Java Sea. 
Sea level rise generated from La Nina phenomenon, in fact, led to various adverse impacts such as erosion, abrasion, and a pool of sea water. Furthermore, to determine the projected sea level for the next few years and the influences of ENSO and La Nina on sea level and coastal cultivated areas, simulation was performed. In prior to the simulation, causal loop diagrams (causal diagrams) was established. Figure 5 presents the causal loop diagram that was established by employing Powersim Constructor 2.5 software.

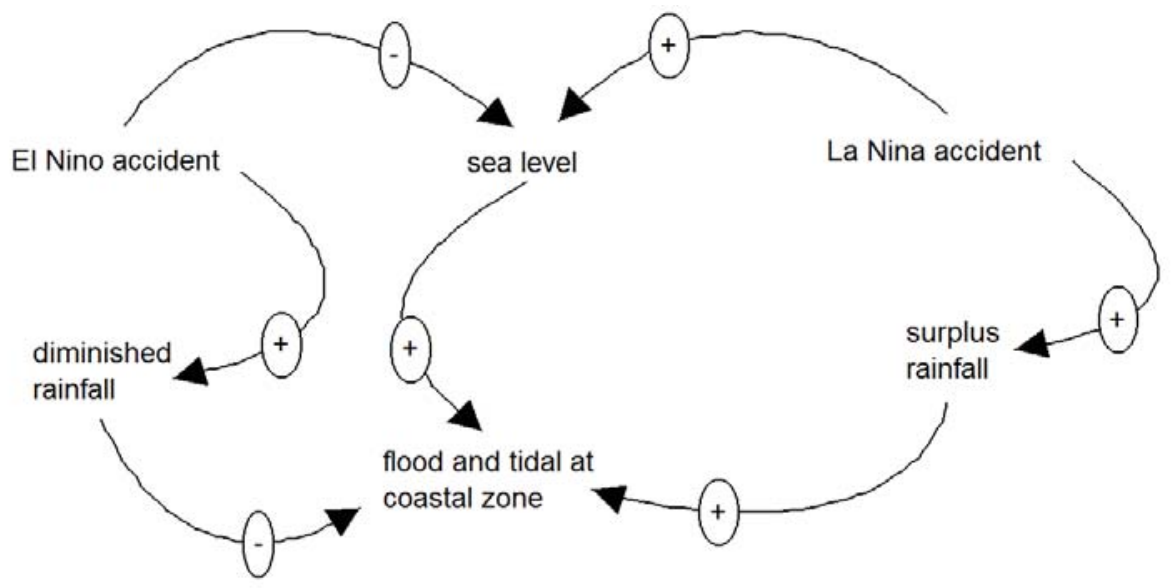

Figure 5. Causal loop diagram in Powersim

Based on Figure 5, it can be explained that sea level rise was an impact of La Nina and would be reduced by powerful El Nino. The phenomenon of El Nino reduced rainfall, while La Nina increased rainfall. Sea level rise as the consequence of global warming as well as La Nina phenomenon potentially created inundation in coastal area. After the establishment of causal loop diagram, the next step was to create a flowchart diagram. Figure 6 presents the flowchart diagram that was constructed by Powersim Constructor 2.5 software.

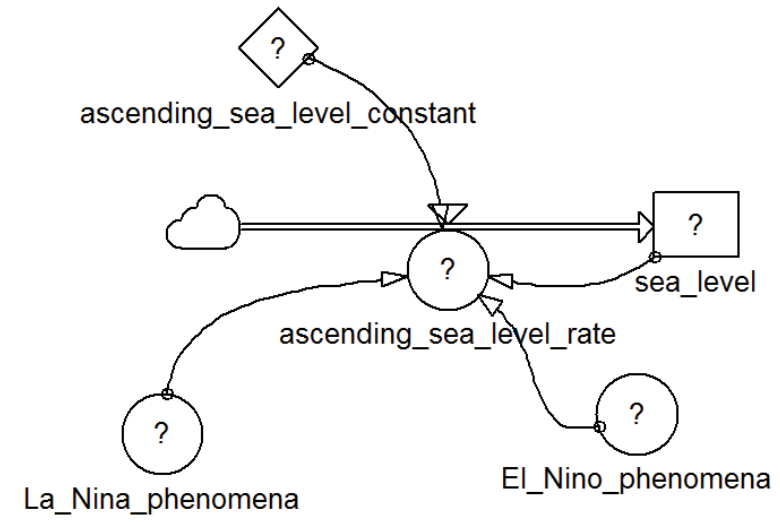

Figure 6. Flowchart diagram of El Nino, La Nina and Sea level.

Assumptions used to run the simulation for sea level were, first, El Nino occurs once in
3 (three) years. Second, La Nina occurs every year. The first parameter for sea level was the level in 1994 amounted to $44.37 \mathrm{~cm}$ and the sea level rise due to global warming of $2.37 \%$. The value of sea level rise due to global warming was obtained from the data of normal sea level. In addition, sea level rise due to La Nina phenomenon was obtained based on the mean sea level during La Nina $(+3.79 \mathrm{~cm})$. Similarly, it was done for the reduction of sea level during El Nino $(-9.36 \mathrm{~cm})$. Subsequently, simulation model was implemented to the data from 1994 to 2100 . The result of the simulation is presented in Table 1.

Table 1. Result of simulation

\begin{tabular}{ccc}
\hline \multirow{2}{*}{ Year } & \multicolumn{2}{c}{ Sea level Projection $(\mathbf{c m})$} \\
\cline { 2 - 3 } & IPCC & Simulation results (Powersim) \\
\hline 2013 & 64.91 & 64.23 \\
2020 & 84.91 & 84.47 \\
2030 & 116.91 & 117.67 \\
2050 & 184.91 & 201.04 \\
2080 & 322.91 & 438 \\
\hline
\end{tabular}

The examination on the result of simulation of the IPCC (1997) and the result of the simulation in this study showed a correlation coefficient $r$ of 0.99 . It showed that the model was accurate. IPCC (1997) in Suhelmi (2013) estimated the global sea level rise from 1990 to 2100 would reach $18-59 \mathrm{~cm}$. 
The result of simulation can be used to forecast the coastal areas (sub-district) in Cilacap Regency that are potential to suffer from flood due to the climate change (El Nino, La Nina, and sea level rise). Table 2 presents the projection when the districts located in the coastal area of Cilacap Regency are inundated by examining the topography of the altitude above mean sea level (AMSL).

Table 2. Projection of inundated coastal zone (sub-district) in Cilacap Regency

\begin{tabular}{llccc}
\hline No. & \multicolumn{1}{c}{ District } & $\begin{array}{c}\text { Altitude above sea } \\
\text { level (m) }\end{array}$ & $\begin{array}{c}\text { Flood occurrence } \\
\text { Projection (Year) }\end{array}$ & $\begin{array}{c}\text { Sea level } \\
(\mathbf{m})\end{array}$ \\
\hline 1. & Kampung Laut & 1 & 2026 & 1.017 \\
2. & Kesugihan & 8 & 2105 & 8.191 \\
3. & Adipala & 8 & 2105 & 8.191 \\
4. & Binangun & 8 & 2105 & 8.191 \\
5. & Nusawungu & 10 & 2114 & 10.199 \\
6. & South Cilacap & 6 & 2093 & 6.101 \\
7. & Central Cilacap & 5 & 2086 & 5.098 \\
8. & North Cilacap & 6 & 2093 & 6.101 \\
\hline
\end{tabular}

Based on Table 2, it can be seen that Kampung Laut sub-districts with an altitude of 1 meter amsl was predicted to suffer from flood in 2026, Central Cilacap district situated at an altitude of 5 meters amsl will be inundated by 2086. South Cilacap and North Cilacap sub-district, both of them are at an altitude of 6 meters amsl were predicted to be flooded in 2093. In addition, three sub-districts of Binangun, Adipala, and Kesugihan, which are located at the altitude of 8 meters amsl were estimated to endure flood in 2105. Last, Nusawungu sub-district was estimated to be inundated in 2114.

\section{Conclusions and Recommendations}

Based on this study, El Nino reduces the climatological rainfall of Cilacap Regency approximately 295 to $1665 \mathrm{~mm}$. Meanwhile, La Nina phenomenon causes surplus rainfall with a range between 189-691 mm/year in compared with the annual climatological rainfall. In addition to diminished rainfall, another impact of ENSO phenomenon was the lowered sea level. When ENSO phenomenon
(El Nino) occurred in South Java Sea, the sea level anomaly in 1994, 1997, and 2002 were, $-11.63 \mathrm{~cm}, 11.5 \mathrm{~cm}$, and $-4.95 \mathrm{~cm}$, respectively. Meanwhile, La Nina phenomenon in 1999 and 2000 altered the sea level anomaly of 2.55 $\mathrm{cm}$ and 5.03, respectively. Hence it can be concluded that the sea level anomaly generated by El Nino decreased the annual sea level of South Java Sea. On the contrary, La Nina brings positive sea level anomaly in which it causes upwelling. The results of sea level projections by using simulation model in this study was compared to the simulation results of IPCC and obtained a correlation coefficient $r$ of 0.99 . Based on the simulation, the eight sub-districts in Cilacap Regency that are located in coastal areas potentially suffer from flood due to the impacts of global warming and La Nina with various estimated year depending on the altitude of each sub-district.

\section{Acknowledgements}

The author thanks to Centre of Atmospheric Science and Technology for the financial support in this research.

\section{References}

Amri, S. N. and T. Arifin. (2016) Adaptation Strategy of Seaweed Cultivation to Face the Climate Change (Case Study on Segoro Anakan Bay Ngadirejo, Pacitan). Forum Geografi. vol. 30. no. 1, July, pp. 34-44.

Ashok, K. and Saji N. H. (2007) On Impact of ENSO and Indian Ocean Dipole events on the sub regional Indian Summer monsoon rainfall, Natural Hazards, vol. 42, no. 2, pp. 273-285.

Estiningtyas, W., F. Ramadhani., E. Aldrian. (2007) Analisis Korelasi Curah Hujan dan Suhu Permukaan Laut Wilayah Indonesia. Jurnal Agromet Indonesia. vol. 21, no. 2, pp: 46-60. 
IPCC. (2007). Climate Change 2007 - The Physical Science Basis, Cambridge University Press, Cambridge.

Lansigan, F.P., W.L. Santos., J. O. Coladilla. (2000) Agronomic impacts of climate variability on rice production in the Philippines. Agric Ecosyst Environment. vol. 82. pp: 129-137.

Ratnaningayu. (2009) Dari Timor ke Krui: Bagaimana petani dan nelayan menghadapi dampak perubahan iklim?, Saresehan iklim, Jakarta, November 2009. Pelangi Indonesia.

Sahu, N., Y. Yamashiki and K. Takara. (2010) Impact Assessment of IOD/ENSO in the Asian Region. Annual Disaster. Prev.Res. Inst., Kyoto University., No. 53B, 2010, 97-103.

Sofian, I. (2007) Simulation of The Java using an Oceanic Feneral Circulation Model, J. Geomatika. vol. 13. no. 2. pp: 1-14.

Subagyono, K and E. Surmaini. (2007) Pengelolaan Sumber Daya Iklim dan Air Untuk Antisipasi Perubahan Iklim. Jurnal Meteorologi dan Geofisika. vol. 8. no. 1, Juli. pp: 27-41.

Suhelmi, I. R. (2013) Pemetaan Kapasitas Adaptif Wilayah Pesisir Semarang dalam Menghadapi Genangan Akibat Kenaikan Muka Air Laut dan Perubahan Iklim. Jurnal Forum Geografi. vol. 27., no. 1. Pp. 81-92.

Susandi, A., I. Herlianti., M. Tamamadin, I. Nurlela. (2008) Dampak Perubahan Iklim Terhadap Ketinggian Muka Laut Di Wilayah Banjarmasin. Jurnal Ekonomi Lingkungan. vol.12, no.2. pp.1-8.

\section{Appendix}
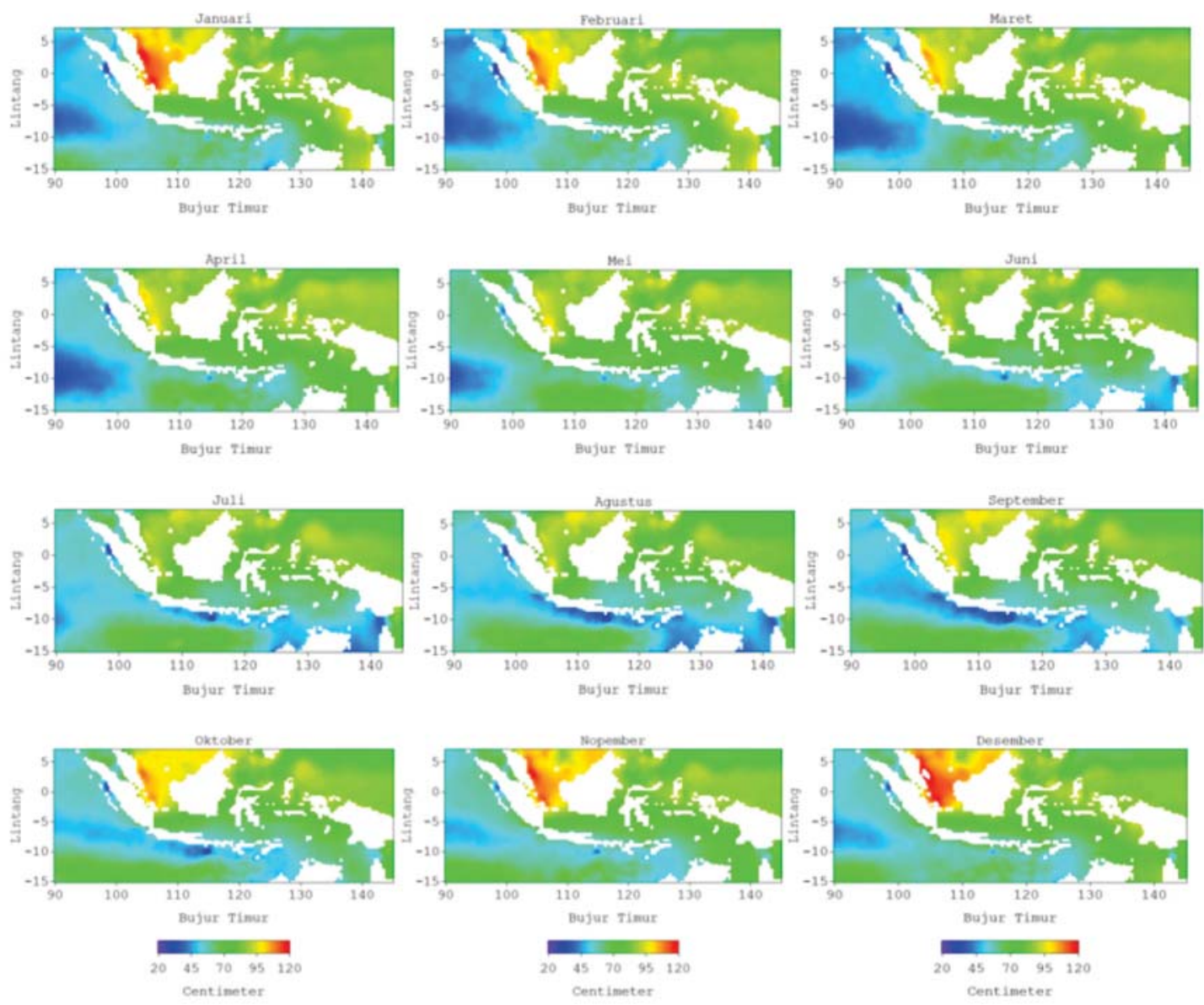

Appendix 1. Monthly sea level. 